\title{
CONSTANTINE'S SUMMUS DEUS AND THE NICENE UNUS DEUS: IMPERIAL AGENDA AND ECCLESIASTICAL CONVICTION
}

This article investigates the gradual metamorphosis of Constantine's doctrine of God primarily with the help of the so-called title-theology ${ }^{1}$. It focuses on the diachronic development of what Constantine called his God in some of his extant letters and speeches, and investigates what these titles might have communicated in the religious context of the fourth century. The resulting picture of the emperor's God is then assessed in the light of the theology of a contemporaneous synodal creed of Nicaea. It will be argued that Constantine's doctrine of God was "orthodox enough", although the articulation of it retained a certain deliberate vagueness, which suited the always expedient pontifex maximus of every religion and sect of his empire ${ }^{3}$.

Hermeneutically speaking, the extant speeches, letters, laws, inscriptions, as well as a whole lot of material evidence, do not enable one to deduce anything definite about Constantine's religious convictions and/or the blessedness of his heart. While one can get to his linguistic signa ${ }^{4}$, his "internal

* Tarmo Toom Ph.D. - Associate Professor of Latin Patristics, School of Theology and Religious Studies, The Catholic University of America, Washington DC, USA, e-mail: TOOM@cua.edu.

${ }^{1}$ Titles or "«acclamatory epithets» became in the imperial period an important medium for the conceptualization of divine presence and efficacy" (A. Chaniotis, Megatheism: the Search for the Almighty God and the Competition of Cults, in: One God: Pagan Monotheism in the Roman Empire, ed. S. Mitchell - P. van Nuffelen, Cambridge 2010, 112-140, at 135); H. Dörries, Das Selbstzeugnis Kaiser Konstantins, Abhandlungen der Akademie der Wissenschaften in Göttingen, Phil.-Hist. Klasse 34, Göttingen 1954, 352-396.

${ }^{2}$ M. Edwards, The Constantinian Circle and the "Oration to the Saints", in: Apologetics in the Roman Empire, ed. M. Edwards et al., Oxford 1999, 261.

${ }^{3}$ Constantine's famous self-designation ó غ̇ंí์ IV 24, ed. F. Winkelmann, GCS (Eusebius Werke 1/1), Berlin 1975, 128, transl. A. Cameron S.G. Hall: Eusebius, Life of Constantine, Oxford 1999) can be taken in a sense that the emperor was "bishop for matters outside the Church", including the religious affairs of the empire.

${ }^{4}$ Constantine himself suggested that words by themselves could be insufficient: "For what profit would there be in words if the disposition of the speaker were left unexamined?" (Oratio ad sanctorum coetum 2, ed. I.A. Heikel, GCS 7 (Eusebius Werke 1), Leipzig 1902, 155, transl. M. Edwards: Constantine and Christendom: The Oration to the Saints, The Greek and Latin Accounts of the Discovery of the Cross, The Edict of Constantine to Pope Silvester, Translated Texts for Historians 39, Liverpool 2003). 
psychological process $[\ldots]$ is undiscoverable"s. In other words, what is accessible is the ambiguous evidence of Constantine's gradually more precise articulation of his concept of God in his extant writings ${ }^{6}$, as well as the fact that Constantine's deeply complex and lifelong growth into Christianity culminated at his baptism in 337, leaving little doubt about how he wanted to be perceived - as the first Christian Roman emperor ${ }^{7}$.

1. Constantine's God according to his Letters and Speeches. The evidence about Constantine's evolving understanding of God is both sketchy and ambiguous, especially before 324 . He was not raised as a Christian ${ }^{8}$. When Constantine had to respond to yet another Frankish raid, he sought help from one of his father Constantius' preferred gods, Apollo, whose temple was in Grand, Vosges. He had a vision of light. So, in 310, a panegyrist suggested that Constantine "saw" (videre) Apollo". On the other hand and by appealing to Constantine's own testimony, Eusebius later contended that the emperor had a vision and a dream in which he saw Christ $^{10}$. Even if the vision was the same phenomenon with different interpretations ${ }^{11}$, the very existence of different interpretations allows one to surmise that the vision/dream was granted to the troubled emperor by a deity whose identity was not so readily apparent. Perhaps Eusebius and Lactantius ${ }^{12}$, among other Christians, afterward graciously helped the emperor to identify this generic deity ${ }^{13}$ and so, after 312 ,

${ }^{5}$ T.D. Barnes, Constantine: Dynasty, Religion and Power in the Late Roman Empire, Blackwell Ancient Lives, London 2011, 80. For what the claim to be a Christian meant in the fourth century, see Edwards, Constantine and Christendom, p. X-XIV.

${ }^{6}$ The process from thought to utterance or writing is a complicated matter involving communicative gaps (Cicero, De inventione II 42, 122; II 48, 142, transl. E.W. Sutton - H. Rackham, The Loeb Classical Library (= LCL) 384, Cambridge 1942; Quintilianus Marcus Fabius, Institutio oratoria VII 6, 1, transl. D.A. Russell, LCL 126, Cambridge 2002). Thus again, even the information coming from Emperor Constantine himself does not provide a direct, problem-free access to his heart and mind. As an emperor, Constantine was capable of spreading "official untruth" whenever it was convenient for advancing his political agendas (Barnes, Constantine, p. 2-6).

${ }^{7}$ Cf. Excerpta Valesiana, Origo Constantini Imperatoris VI 33, in: Ammianus Marcellinus, Res gestae, ed. and transl. J.C. Rolfe, vol. 3: Libri XXVII-XXXI, LCL 331, Cambridge 1939, 526.

${ }^{8}$ Cf. Constantinus I Imperator, Oratio ad sanctorum coetum 11.

${ }^{9}$ Cf. Anonymus, Panegyricus Constantino Augusto dictus VI 21, 3-4; 22, 1, ed. and transl. R.A.B. Mynors in: C.E.V. Nixon - B.S. Rodgers, In Praise of Later Roman Emperors: The Panegyrici Latin, transl., introduction and historical commentary, with the Latin Text, Berkeley 1994, 248-251 (English), 583 (Latin). It has to be reiterated, however, that laudatory speeches, which follow particular conventions, are very poor indicators of reality as well as of what an orator "really" thought and believed - and even poorer indicators of what emperors may have thought and believed.

${ }^{10} \mathrm{Cf}$. Eusebius, Vita Constantini I 28-32.

${ }^{11}$ Cf. P. Weiss, The Vision of Constantine, "Journal of Roman Archeology" 16 (2003) 237-259.

${ }^{12}$ Cf. Lactantius, De mortibus persecutorum 44, ed. and transl. J.L. Creed, Oxford 1984.

${ }^{13}$ Cf. Eusebius, Vita Constantini I 32, 1-2 (cf. I 27, 1 "a god") and a still later but more detailed 
Constantine did not object to the idea that the God he had seen was the Christian God $^{14}$.

The problem with the identity of the God in Constantine's famous vision is precisely that the ex post facto Christian construal of the event comes from Eusebius $^{15}$ and Lactantius in the 320 s and in the light of Acts $26,13^{16}$. Thus, once again, it is a real possibility that originally, the identity of the God who appeared to Constantine was not entirely clear to the emperor himself. In addition, we do not even know whether he was initially interested in making it very clear. In time, however, Constantine's growing attachment to the Christian God seemed to have come closer to what the Christian and public versions of his vision had already stated about the God manifested in the emperor's special vision ${ }^{17}$.

elaboration in Sozomen (HE I 3, ed. J. Bidez - G.C. Hansen, GCS NF 4, Berlin 1995, transl. Nicene and Post-Nicene Fathers [= NPNF], Series II, vol. 2).

${ }^{14}$ Cf. Eusebius, Vita Constantini IV 9 and Mt 24, 30; Weiss, The Vision of Constantine, p. 252; P. Barceló, Constantins Visionen: Zwischen Apollo und Christus, in: Konstantin und das Christentum, ed. H. Schlange-Schöningen, Darmstadt 2007, 133-149. Barceló believes, however, that seeing Apollo and Christ were separate visions.

${ }^{15}$ Eusebius' Vita Constantini provides "a powerful portrait of the prototypical Christian emperor" (H.A. Drake, What Eusebius Knew: The Genesis of the "Vita Constantini", CPh 83:1988, 20-38, at 32; see Eusebius, Vita Constantini I 11,2). In the hagiographical Laus Constantini 11, 7 , ed. I.A. Heikel, GCS 7 (Eusebius Werke 1), Leipzig 1902, transl. H.A. Drake: In Praise of Constantine: A Historical Study and Translation of Eusebius' Tricennial Orations, Berkeley 1975, Eusebius asked God, "I pray that I may be the kind of interpreter of your [i.e., Constantine's] intentions and become the reporter of your devout soul". Unfortunately, we do not know whether this prayer was ever answered or not. Constantine vowed to Eusebius, that he really saw a vision, but he did not vow that the interpretation Eusebius provided was entirely accurate.

${ }^{16}$ Curiously, Constantine never mentioned his private vision in his lengthy Oratio ad sanctorum coetum.

${ }^{17}$ In his Constantine and the Bishops: The Politics of Intolerance, Baltimore 2000, 187-189, Drake analyzes the retrospective nature of one's interpretation of his/her conversion experience. Hostile ancient literary sources push the "moment" of Constantine's alleged conversion to much later in his life. In 369, Eutropius suggested that Constantine "changed somewhat from his pleasant mildness of spirit" and eventually had his son Crispus and wife Fausta killed (Breviarium ab urbe condita X 6, 3, ed. C. Santini, Bibliotheca Scriptorum Graecorum et Romanorum Teubneriana, Stuttgart 1979, transl. H.W. Bird: The breviarium ab urbe condita of Eutropius, Translated Texts for Historians 14, Liverpool 1993). Accordingly, a sixth century historian Zosimus suggested that seeking forgiveness for his crimes as well as advice from philosopher Sopater, Constantine, who "still practiced the ancestral religion", turned to the Christian God only after these tragic events (Zosimus, Historia nova II 29, 1-4, ed. F. Paschoud: Zosime, Historie nouvelle, t. 1: Livres I-II, Paris 1971, transl. R.T. Ridley: New History, Byzantiana Australiensia 1, Sydney 1982; cf. a semi-extant ecclesiastical history of Philostorgius (HE II 4b, ed. J. Bidez - F. Winkelmann, GCS 21, Berlin 1972, transl. P.A. Amidon: Philostorgiu, Church History, Writings from the Greco-Roman World, Atlanta 2007), and Sozomen (HE I 5) who dismisses this explanation). In Constantine and Christianity: Ancient Evidence and Modern Interpretations, ZACh 2 (1998) 274-294, at 276, Barnes assesses, "Any writer about Constantine is constantly compelled to assess the relative value of different sources and evaluate contradictory statements in partisan authors". 
Constantine's vision of light, a halo-phenomenon, also opened up the interpretative possibility that it was the supreme Sun-god ${ }^{18}$, Sol Invictus ${ }^{19}$, whom he had seen and who had become his protector ${ }^{20}$. As is well known, from 310 to about 325, the images of Sol Invictus appeared on imperial coins next to the images of Constantine ${ }^{21}$. However, imperial coins were not bumper-stickers on which people pouring out their souls announced their deepest convictions. Imperial coins conveyed official religious messages and they could in no way determine whether the depicted God was understood as the sun in the sky or a verus $\mathrm{sol}^{22}$. Nevertheless, there was a lucratively convenient conceptual overlap between the Sun-god and Christ, whom Scripture described with several sun-metaphors ${ }^{23}$. In his letters, Constantine often employed the polysemous sun-analogy to refer to $\mathrm{God}^{24}$ and in 321 , he established Sun-day as the day of rest, which also happened to celebrate the resurrection of Christ.

Now, what is the evidence concerning Constantine's "doctrine of God" ( $\tau$ ò $\tau o \hat{v} \Theta \varepsilon o \hat{v} \delta o ́ \gamma \mu \alpha$ ) in his letters and speeches? ${ }^{25}$ The language about God that Constantine used in his correspondence to Miltiades, Chrestus, Caecilian, and Anullinus in 310s, was not that different from the official language of Licinius' letter of 313 (erroneously dubbed as the "Edict of Milan"26).

${ }^{18}$ Apparently, it was a common understanding that "Sol was in some sense the supreme deity who subsumed all others - a form of quasi-monotheism" (A. Doug Lee, Traditional Religions, in: The Cambridge Companion to the Age of Constantine, Cambridge 2005, 159-179, at 162). Cicero (De natura deorum 2, 27, transl. H. Rackham, LCL 268, Cambridge Mass. 1933) perceived a link between Sol and solus, but this does not necessarily mean that the existence of other lower gods was thereby denied.

${ }^{19}$ Emperor Aurelian had attributed his eastern victories to the assistance of Sol Invictus and erected a temple in this god's honor in Rome in 270s (S. Berrens, Sonnenkult und Kaisertum von den Severern bis zu Constantin I [193-337 n. Chr.], Historia 185, Stuttgart 2004, 89-97).

${ }^{20}$ Cf. J. Bardill, Constantine, Divine Emperor of the Christian Golden Age, Cambridge 2012, 28a-63b, 100b-104b. "Die Vision war das Mittel, die in Frage kommende Schutzgottheit zu finden" (Barceló, Constantins Visionen, p. 133).

${ }^{21}$ Cf. Berrens, Sonnenkult und Kaisertum, p. 150-162. "The most significant factor in guiding the choice and description of divinities on coins [...] seems to have been the relationship of the god in question to the emperor or the empire" (J. Williams, Religion and Roman Coins, in: A Companion to Roman Religion, ed. J. Rüpke, London 2007, 143-163, at 156).

${ }^{22}$ Ambrose's hymn Splendor Paternae gloriae calls Jesus Christ "the true sun" (verus [que] sol), cf. A.S. Warpole, Early Latin Hymns, Cambridge 1922, 36.

${ }^{23}$ E.g., Is 60, 20; Mal 4, 2; Mt 17, 2; and Rev 10, 1. Tertullian testifies to the fact that many ignorant people took the Christian God to be the Sun (Ad nationes 1, 13, CCL 1, ed. J.W.P. Borleffs, Turnhout 1954, 32, transl. Ante-Nicene Christian Library 11). See R. Markus, The End of Ancient Christianity, Cambridge 1990, 103-106.

${ }^{24}$ Cf. e.g., Eusebius, Vita Constantini I 71, 4; Optatus, Contra Parmenianum Donatistam 5, CSEL 26, ed. C. Ziwsa, Vienna 1893, transl. M. Edwards: Optatus, Against Donatitsts, Translated Texts for Historians 27, Liverpool 1997.

${ }^{25} \mathrm{Cf}$. Constantinus I Imperator, Oratio ad sanctorum coetum 11.

${ }^{26}$ O. Seeck, Das sogenannte Edikt von Mainland, ZKG 10 (1891) 381-386; Barnes, Constantine, p. 93-97. 
Constantine operated with flexible designations, such as "divine Providence"

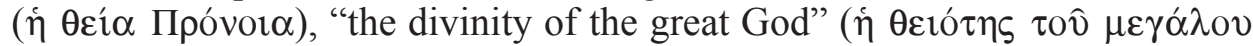

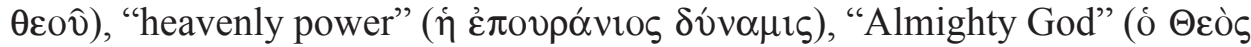

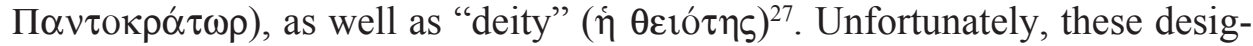
nations neither say anything particular about Constantine's concept of God, nor are they exclusively Christian vocabulary ${ }^{28}$.

An exception is Constantine's letter to catholic bishops after the Council of Arles in $314^{29}$. This letter stands out because it is the first time that Constantine mentions Christ in his letters ("Christ Savior" [Christus Salvator], "mercy of Christ" [clementia Christi], "judgment of Christ" [iudicium Christi], and "Christ's teaching" [Christi magisterium]). These designations appear next to the usual ones: "Almighty God" (Deus omnipotens), "the supernatural power" (superna potentia), and "divinity" (divinitas) $)^{30}$. In fact, it is difficult to explain this anomalous sudden appearance of the name "Christ" in a letter written by Constantine - unless his public preference of Christianity is taken to justify it satisfactorily. If this letter is authentic, was the upstart emperor trying to please his episcopal readership? ${ }^{31}$ Yet about ten years later, Constantine's letter to bishop Alexander and his deacon Arius never mentioned the name "Christ". Thus, were some Christian co-authors (or, speechwriters ${ }^{32}$, advisors, and editors) involved in the composition of this letter? We just don't know for sure. Was the name "Christ" interpolated later? The critical text does not indicate this ${ }^{33}$. Thus, it seems that the sudden, multiple occurrence of the name "Christ" in a letter written by Constantine testifies to the emperor's knowledge of Christianity, but again, it does not necessarily say anything definite about his own religious convictions or his doctrine of $\operatorname{God}^{34}$.

${ }^{27}$ Constantine's letters in Eusebius (HE X 5-7, ed. E. Schwartz - T. Mommsen, GCS (Eusebius Werke 1/2), Berlin 1999, transl. NPNF II/1).

${ }^{28}$ A "pagan" grammarian Maximus of Madaura contended that "God is the name common to all religions" (nam Deus omnibus religionibus commune nomen est) (Augustinus, Epistula 16, 1, ed. A. Goldbacher, CSEL 34/1, Vienna 1895, transl. R. Teske: The Works of St. Augustine: A translation for the 21st Century [= WSA], ed. J. Rotelle - B. Ramsey, vol. II/1, New York 2001).

${ }^{29}$ Cf. Optatus, Contra Parmenianum Donatistam 5, in: J.L. Maier, Le Dossier du Donatisme, vol. 1, TU 134, Berlin 1987, 167-171. See Constantine's letter to Eusebius in Vita Constantini (IV 35, 1), which was written late in the emperor's life.

${ }^{30}$ Constantine's other letters concerning Donatist matters likewise employ titles, such as "heavenly divinity (divinitas caelestis)", "the highest divinity/the supreme God" (summa divinitas/summus deus), and "Almighty God" (Deus omnipotens) (Optatus, Contra Parmenianum Donatistam 5-7; ibidem 9-10).

${ }^{31}$ Constantine's past in the court of a persecutor Diocletian may have provided the emperor a motive for appearing particularly Christianity-friendly in his communication with several influential bishops.

${ }^{32}$ Eusebius (Vita Constantini IV 29, 1) contends that Constantine did not use speechwriters and at times, this may well have been so.

${ }^{33}$ Cf. CSEL 26, 208-210.

${ }^{34}$ According to Eusebius, already early on, Constantine took "the priests of God as his ad- 
Right after his victory over Licinius, Constantine learned about the "divisive quarrels with divine doctrines as an excuse" between bishop Alexander and presbyter Arius ${ }^{35}$. So, in 324, the emperor sent Ossius of Córdova to Alexandria ${ }^{36}$, bearing a stern letter of warning to the above named bickering theologians ${ }^{37}$, The fuss had started with a disagreement over a scriptural passage $^{38}$. What seems to have concerned the emperor, however, was not so much exegetically based doctrinal orthodoxy, but rather the fact that "fellowship was repudiated, and the most holy people was divided in two and forsook the concord of the common body" 39 . For Constantine, it was the resulting schism that was an "intolerable madness" ${ }^{40}$. The emperor rhetorically diminished the exegetical/doctrinal nuances - even as these concerned the central doctrine of God - to "extremely trivial [matters]", "some futile point[s] of dispute", and "verbal quarrels" 41 . The religious well-being of the empire just did not need to be disturbed by the controversial theoretical minutiae that Alexander

visers" (Vita Constantini I 32, 3). See W. Eck, Eine historische Zeitenwende: Kaiser Constantins Hinwendung zum Christentum und die gallischen Bischöfe, in: Konstantin der Große - Kaiser einer Epochenwende, ed. F. Schuller - H. Wolff, Lindenberg 2007, 69-84. Most importantly, Lactantius allegedly read his Institutes at the court of Constantine in Trier (E. DePalma-Digeser, The Making of a Christian Empire: Lactantius \& Rome, Ithaca 2000, 13). Yet, one's knowledge about a religion does not make him/her a follower of this religion and vice versa, one's ignorance of a religion does not prevent him/her from being a follower of a given religion. Unfortunately, this distinction is missing in Ch.M. Odhal's Constantine's Epistle to the Bishops at the Council of Arles: A Defence of Imperial Authorship, JRH 17 (1993) fasc. 3, 274-289.

${ }^{35}$ Cf. Eusebius, Vita Constantini II 61, 4.

${ }^{36}$ Cf. Athanasius, Apologia contra Arianos 74, ed. H.G. Opitz: Athanasius Werke II/1, Berlin 1936, transl. NPNF II/4; Socrates, HE I 7, ed. G.C. Hansen, GCS NF 1, Berlin 1995, transl. NPNF II/2.

${ }^{37}$ Cf. Eusebius, Vita Constantini II 63-73; Sozomenus, HE I 16.

${ }^{38}$ Cf. Eusebius, Vita Constantini II 69, 1; II 70. Most likely, it was Prov 8, 22-25, a text which, according to Epiphanius (Panarion LXIX 12, 1, ed. J. Dummer, GCS 37, Berlin 1985), sparked the fourth century Trinitarian controversy. Hilary (De Trinitate 12, 1, PL 10, transl. S. McKenna: Fathers of the Church 25, Washington 1954) called Prov 8, 22 "the most powerful wave of their [i.e., Homoean] storm" and Basil of Caesarea (Contra Eunomium II 20, ed. B. de Sesboüé, SCh 305, Paris 1983, trans: M. DelCogliano - A. Radde-Gallwitz: Fathers of the Church 122, Washington 2011) said that Eunomians "have recourse to the text of Solomon [i.e., Prov 8, 22] and from it, as if from a base of military operations, they launch an assault on the faith".

${ }^{39}$ Eusebius, Vita Constantini II 69, 1, GCS (Eusebius Werke 1/1) 75; cf. ibidem I 44-45; III 60, 6; IV 42, 1.

${ }^{40}$ Ibidem II 66, GCS (Eusebius Werke 1/1), 74.

${ }^{41}$ Ibidem II 68, 2, GCS (Eusebius Werke 1/1), 75; cf. ibidem II 69, 1; II 71, 3. Emperor Constantine also suggested that the precise details of the controversy were even not worth knowing - "this very silly question, whatever it actually is" (ibidem II 71, 6). Eusebius, in turn, had his own good reasons for highlighting Constantine's apparent dismissive neutrality, although the emperor's consequent actions indicated that perhaps he had already turned against Arius; cf. T.G. Elliott, Constantine's Preparations for the Council of Nicaea, JRH 17 (1992) 127-137. After all, one of Arius' most important supporters, Eusebius of Nicomedia, had been a prominent figure in the court of Constantine's rival Licinius. Evidently this mattered. 
and Arius were fighting about. Theological differences should be peacefully tolerated, especially in matters which were way above human reason anyhow (i.e., the question of the Trinity). "We must [...] avoid being talkative in such matters" 42 . To make the long story short, Constantine reasoned that the public religion of empire needed to be cohesive and inclusive-specifics were of secondary importance!

Constantine set an example in this very letter. The designations that he used to speak about God were acceptable for Alexander, Arius, and whoever else happened to read the imperial correspondence: for example, "God"

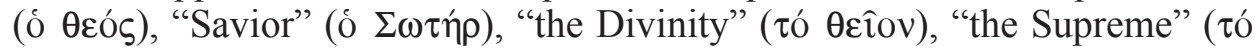

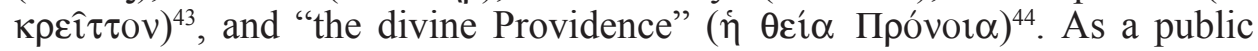
letter-even though addressed to Christians, it did not include any speculative discussions about the divine nature or birth, and never mentioned Jesus Christ and/or the Holy Spirit. In fact, Constantine expresses "no theological opinion about the matter other than that the controversial issue is no problem"45.

However, despite his cautious statesman-like restraint, the emperor, who was "break[ing] down in tears" because of the controversy between Alexander and Arius ${ }^{46}$, soon faced the challenge of being more specific about what he exactly meant by "God" or "Deity"

A glimpse of the shape which the emperor's understanding of God was steadily taking can be seen from his letter to eastern provinces about imperial policies, sent in $324^{48}$. Again, Constantine made his case by employing the

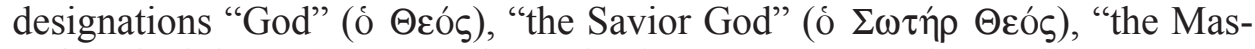

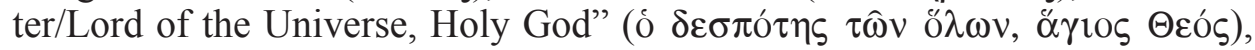

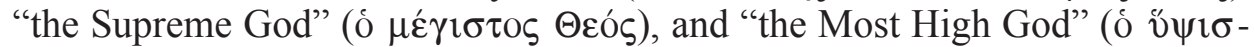

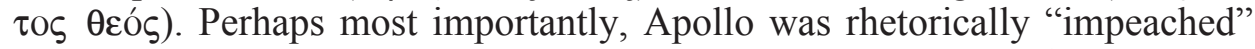
and "your Son" (ó бov̂ viós) (i.e., Jesus Christ) "inaugurated" ${ }^{49}$. No doubt,

${ }^{42}$ Eusebius, Vita Constantini II 69, 3, GCS (Eusebius Werke 1/1), 75.

${ }^{43}$ Cf. Dörries, Das Selbstzeugnis Kaiser Konstantins, p. 353, n. 1.

${ }^{44}$ Constantine's letter to the provincials of Palestine (Eusebius, Vita Constantini II 24-42, papyrus P. Lond. 878), which was his first communication with the eastern provinces, likewise uses

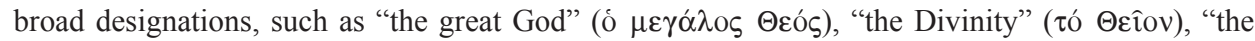

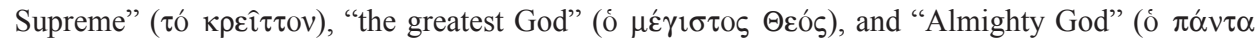
$\delta v v \alpha \tau o ́ \varsigma$ $\theta \varepsilon o ́ \varsigma)$.

${ }^{45} \varnothing$. Norderval, The Emperor Constantine and Arius: Unity in the Church and Unity in the Empire, StTh 42 (1988) 113-150, at 121.

${ }^{46}$ Cf. Eusebius, Vita Constantini II 72, 1. Among other reasons, such almost ridiculous emotionality has raised the issue of authenticity of this letter ( $\mathrm{P}$. Batiffol, La paix constantinienne et le catholicisme, Paris 1914³, 315-320).

${ }^{47}$ If Raymond Van Dam (The Roman Revolution of Constantine, Cambridge 2007, 248-251) is right about the tight link between the notions of one God and one emperor, then Constantine may indeed have had vested interests in articulating more precisely his concept of God than he otherwise would have.

${ }^{48}$ Cf. Eusebius, Vita Constantini II 47-61.

${ }^{49}$ Even panegyrists dropped the name of Apollo and other gods in their speeches after 312 and 
Constantine was signaling his wish to come across as a believer in the Christian God. The emperor's partisan rhetoric was abundantly supported by his pro-Christianity legislation, extensive church-building projects, and lavish donations to Christian causes ${ }^{50}$.

A noteworthy detail for the current investigation is Constantine's in-

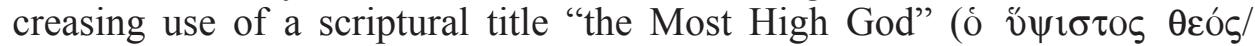
Deus Summus $)^{51}$. This title offered particular promise for advancing a broad, relatively neutral, "ecumenical" monotheism in the whole empire and thus to satisfy the religious tastes of many ${ }^{52}$. Such unspecified monotheism supposedly suited most imperial citizens - adherents of the cults of Theos Hypsistos and Sol Invictus, Hermetists, "pagan" henotheists ${ }^{53}$, as well as Jewish and Christian monotheists. In other words, the marvelously elastic designation "Most High God" enabled Constantine "to tolerate many religions in his Empire while he aimed at the final victory of one" 54 . Constantine's alleged filling the designation "Most High God" with a particular, personally preferred religious content did not thereby ban other interpretations ${ }^{55}$. Just like the chi-rho sign had a wonderfully open double meaning - one for Christians, another for

referred only to supreme deity (summus) and divine force (vis) or mind (mens) (Anonymus, Paegyricus Constantino Augusto dictus XII 26, 1).

${ }^{50}$ Yet again, imperial policies should not be mistaken for anyone's personal beliefs (H.A. Drake, Policy and Belief in Constantine's "Oration to the Saints", StPatr 19 (1989) 43-51).

${ }^{51}$ E.g., Gen 14, 18; Num 24, 16; Mic 6, 6; Mk 5, 7; Lk 1, 32-35; 2, 14; Acts 16, 17.

${ }^{52}$ The modern term "monotheism" can be defined in various ways, inclusively and exclusively (P. van Nuffelen, Pagan Monotheism as a Religious Phenomenon, in: One God, 16-33, at 17-21). For example, the primarily eastern cult of Theos Hypsistos, which existed from the Hellenistic times to the fifth century, elevated the supreme god above other prominent gods, and at other times, identified it with other highest gods, such as Zeus, Nemesis, and Helios; cf. S. Mitchell, The Cult of Theos Hypsistos between Pagans, Jews, and Christians, in: Pagan Monotheism in Late Antiquity, ed. P. Athanassiadi - M. Frede, Oxford 1999, 81-148. Nicole Belayche, too, has demonstrated that the designation Theos Hypsistos can mean a god "exclusive of all fellow-deities" as well as a "top-god" which is primus inter pares (Hypsistos: A Way of Exalting the Gods in Graeco-Roman Polytheism, in: The Religious History of the Roman Empire: Pagans, Jews, Christians, ed. J.A. North - S.R.F. Price, Oxford Readings in Classical Studies, Oxford 2011, 139-174 [original: ARg 7 (2005) 219-232]).

${ }^{53}$ In their apophatic elevation of the one Most High God, devotees employed a Latin triple superlative exsuperantissimus for Jupiter, or the Greek $\pi \alpha v v$ $\psi 1 \sigma \tau$ เ

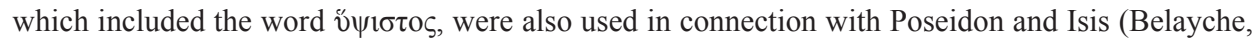
Hypsistos, p. 142-143). Nectarius, a pagan official in Numidia, gladly accepted Augustine's admonition to turn to the worship of the Most High God (ad exsuperantissimi Dei cultum) (Epistula 103, 2).

${ }^{54}$ M. Edwards, Pagan and Christian Monotheism in the Age of Constantine, in: Approaching Late Antiquity: The Transformation from Early to Late Empire, ed. S. Swain - M. Edwards, Oxford 2004, 211-232, at 211.

${ }^{55}$ Cf. S. Mitchell (Further Thoughts on the Cult of Theos Hypsistos, in: One God, 167-208, at 168) argues that Theos Hypsistos was an abstract and nameless god whose worshippers "retained a common underlying concept of a specific divine personality behind this appellation". See Celsus' defense of polynomy in Origen (Contra Celsum V 41, ed. M. Marcovich, Origenis contra Celsum libri VIII, Leiden 2001, transl. H. Chadwick: Origen, Contra Celsum, Cambridge 1965). 
"pagans" 56 - so could the God-vocabulary be used to denote various things. Officially, Constantine's faith as the faith of the first man of the empire just had to be some sort of "anonymous and «catch-all» monotheism"57, which lacked too specific dogmatic content, but which all enlightened minds of different persuasions could easily affirm ${ }^{58}$.

By far the best evidence for Constantine's developing understanding of God is his Oratio ad sanctorum coetum ${ }^{59}$, a speech which was delivered immediately before the Council of Nicaea ${ }^{60}$. This two-hour-or-so speech was given in a "Roman tongue" and then translated into Greek ${ }^{61}$. Thus, for the lack of a better alternative, the words of the Oratio ad sanctorum coetum are taken here as Constantine's own words in a sufficiently adequate translation. Hopefully it is still possible to get a fairly good sense of "what got said" 62 .

The overall goal of Constantine's Oratio ad sanctorum coetum was to show that the emperor was all about fostering the goodwill of the Supreme God, who was depicted as Constantine's illuminator and protector ${ }^{63}$, and consequently peace on earth and unity in the church. These topics fitted well under the main theme of his speech - providence ${ }^{64}$. Previously, Constantine had used the word "providence" simply as one of the names for his God, but in his

${ }^{56}$ R.L. Fox, Pagans and Christians, New York 1987, 616; Bardill, Constantine, p. 220a-222b.

${ }^{57}$ P. Veyne, When Our World Became Christian 312-394, transl. J. Lloyd, Cambridge 2010, 7.

${ }^{58}$ The generic prayer which Constantine provided for his soldiers to be said every Sunday suited persons of any religious persuasion: "You alone we know as God, You are the King we acknowledge, You are the Help we summon" (Eusebius, Vita Constantini IV 20, 1). This can be compared to a public prayer that Licinius' army recited before the decisive battle with Maximinus in 313. It started with the words "O God most high, we pray to you", and ended with "Hear us, O holy and most high God [here arguably Jupiter]" (Lactantius, De mortibus persecutorum 46, 1-7).

${ }^{59}$ The Oratio ad sanctorum coetum is the only theological speech of Constantine which is extant (cf. Eusebius Vita Constantini IV 29-32).

${ }^{60}$ Although arguments rather than scholarly "bolshevism" should decide the matter, the majority of scholars seem to date it to 324/325. See the charted overview in Klaus M. Giradet (Der Kaiser und sein Gott: Das Christentum im Denken und in der Religionspolitik Konstantins des Grossen, Millenium-Studien 27, Berlin 2010, 108-123), who himself argues for an earlier date and for the city of Trier, mostly because of the heavy presence of Lactantius' ideas in Constantine's Oratio ad sanctorum coetum. For parallels between Lactantius' works and Constantine's Oratio ad sanctorum coetum, see the notes in GCS 7 (Eusebius Werke 1); for the similarity of the respective concepts of God, D. de Decker, Le Discours à l'Assamblée des Saints attribué à Constantin et l'oeuvre de Lactance, in: Lactance et son temps, ed. J. Fontaine - M. Perrin, Théologie Historique 48, Paris 1978, 75-87; and the understanding of both men vis-à-vis Hermetism, DePalma-Digeser, The Making of a Christian Empire, p. 68-78 and 136.

${ }^{61}$ Cf. Eusebius, Vita Constantini IV 32.

${ }^{62}$ I refer to the Stoic concept of lekton and Augustine's concept of dicibile.

${ }^{63}$ By implication, anyone who dared to be against Constantine was also and inevitably against his divine "unconquerable ally" (Constantinus I Imperator, Oratio ad sanctorum coetum 24-26).

${ }^{64}$ Cf. H.A. Drake, The Impact of Constantine on Christianity, in: The Cambridge Companion to the Age of Constantine, p. 111-136. 
Oratio ad sanctorum coetum, Providence is depicted hypostatically ${ }^{65}$ and is somehow included within the Godhead ${ }^{66}$.

Already in the opening paragraphs of his Oratio ad sanctorum coetum, and much like in his letter of 314 to catholic bishops, the emperor leaves no doubt that, while speaking about the Supreme God, he is speaking about the Christian God ${ }^{67}$. Next to the generic word "God" (ó Orós) and the equally generic adjective "divine" ( $\theta \varepsilon \hat{\imath}$ ov), he employs names such as "Savior"

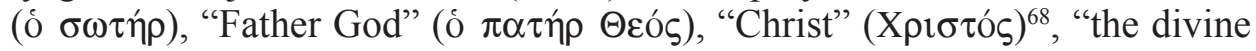

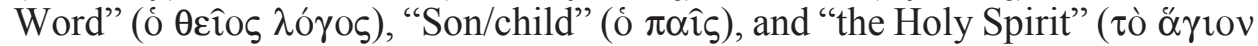
$\pi v \varepsilon \hat{v} \mu \alpha)^{69}$. Somehow God's Son, the begotten one, shares in God's essence (ov $\left.\sigma^{\prime} \alpha \theta \varepsilon \circ \hat{v}\right)^{70}$, somehow the Father and the Son are the Creator God $^{71}$, and somehow the Holy Spirit is divine and eternal as well ${ }^{72}$.

${ }^{65} \mathrm{Cf}$. Constantinus I Imperator, Oratio ad sanctorum coetum 3 and 25. One of the possible sources of Constantine's ideas, Calcidius, mentions the Highest God after whom comes Providence, an "intelligible essence", which is identified with the vov̂s (On Fate 176 in J. den Boeft, Calcidius on Fate: His Doctrine and Sources, Philosophia Antiqua 18, Leiden 1970, 85).

${ }^{66}$ It is difficult to figure out exactly what status Constantine ascribes to Providence. In Oratio ad sanctorum coetum 8 , he emphasizes the unity of one God by saying that "reason and providence are God" ( intended between the Word and Providence or not. In Oratio ad sanctorum coetum 17, Constantine speaks of the providence of Christ, and in Oratio ad sanctorum coetum 11, where Constantine gives thanks to "Christ our God and Savior, the supreme providence of the great God", the epexegetical usage suggests that Christ is identified with Providence. Cf. Dörries, Das Selbstzeugnis Kaiser Konstantins, p. 355.

${ }^{67}$ In addition, Constantine (Oratio ad sanctorum coetum 11 ) pointed out rather confidently that "I have rehearsed $[\ldots]$ the doctrine of God [...] not ignorantly, like many, nor from conjecture or guessing". Rhetorically, he excuses himself from any possible blunders by saying that, since he is "not looking for exactitude of learning", his audience should appreciate at least "the faithfulness of [his] attempt" (Oratio ad sanctorum coetum 2).

${ }^{68}$ Later, in Constantinus I Imperator, Oratio ad sanctorum coetum 15 and 18, also "Jesus".

${ }^{69}$ Constantinus I Imperator, Oratio ad sanctorum coetum 1-9, GCS 7, 154-164. In Chapters 23-25 and somewhat unexpectedly, Constantine switches exclusively to the all-purpose designation "divine" ( $\theta \varepsilon \hat{\imath} 0 v)$.

${ }^{70} \mathrm{Cf}$. ibidem 6.

${ }^{71}$ In Oratio ad sanctorum coetum 1, Constantine calls God "all-mothering nature ( $\pi \alpha \mu \mu \eta \dot{\tau} \tau \varepsilon 1 \rho \alpha$

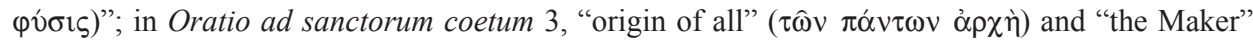

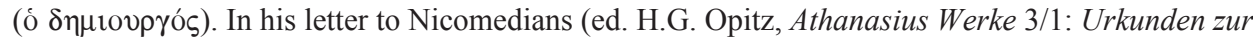
Geschichte des arianischen Streits 318-328, Berlin 1934, nr 27, 2), however, the emperor says the

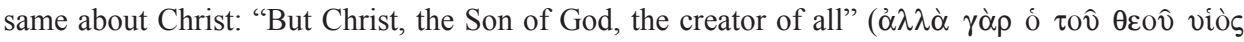

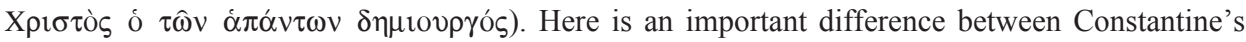
theology and that of his alleged sources. Numenius thinks that while the first, supreme God is inactive, the second god is the creator god and is also distinct in its ov $\sigma i \alpha$ (Frg. 11, 12, 15, 16, and 21 [Des Places]). Cf. J.M. Dillon, The Middle Platonists, 80 B.C. to A.D. 220, Ithaca 1977, 367-369 and M. Hillar, From Logos to Trinity: The Evolution of Religious Beliefs from Pythagoras to Tertullian, Cambridge 2012, 183-189.

${ }^{72}$ Cf. Constantinus I Imperator, Oratio ad sanctorum coetum 9. 
One should note that, in the spirit of his letter to Alexander and Arius, Constantine does not take sides in the rapidly spreading Alexandrian controversy $^{73}$, but reminds his Christian audience ${ }^{74}$ that inquiries into that which is above human nature leads "most of us away from the truth" - and even to the destruction of those who know better, but differ from the opinion which happens to be accepted ${ }^{75}$. Perhaps this is an imperial warning (among others, to Eusebius of Nicomedia! $!^{76}$ ) that "foolish thoughts" about what is beyond human comprehension - the essence of God - are pointless and may have many tragic consequences ${ }^{77}$. Yet, the emperor goes against his own advice in Oratio ad sanctorum coetum 9-11, where he takes a shot at that which is precisely "beyond human comprehension".

So, in the Oratio ad sanctorum coetum, Constantine presents his doctrine of God with the help of the master of understanding the intelligible "things" - Plato. Precisely to what extent Constantine agreed with Plato about God is far from clear though ${ }^{78}$. He certainly appreciated what Plato said about the highest, transcendent God, but also regretted the fact that the philosopher introduced "a host of gods", thereby threatening to compromise the original and unique status of the "Most High" God".

This brings up an intriguing question of Constantine's take on henotheism - a view which was popular among the philosophically enlightened nonChristians ${ }^{80}$. For imperial purposes of securing concord between various religions, there was definitely a sufficient common ground between Christian

${ }^{73}$ Cf. Edwards, The Constantinian Circle and the "Oration to the Saints", p. 260.

${ }^{74}$ Arguably, the Oratio ad sanctorum coetum was delivered to Eusebius of Nicomedia, his clergy, congregation, and candidates for baptism (T.D. Barnes, Constantine's Speech to the Assembly of the Saints: Place and Date of Delivery, JTS 52 (2001) 26-36, at 34).

${ }^{75}$ Constantine mentions the examples of Socrates and Pythagoras (Oratio ad sanctorum coetum 9).

${ }^{76}$ Eusebius of Nicomedia was about to give the welcoming address at the council of Nicaea (Eusebius, Vita Constantini III 11, a text which actually says simply "Eusebius"; cf. Sozomen, HE I 19: Eusebius of Caesarea; Theodoretus, HE I 6, ed. L. Parmentier - G.C. Hansen, GCS 44, Berlin 1998, transl. NPNF II/3: Eusthatius of Antioch), soon after which he was exiled, chastised in a harsh letter by Constantine (Theodoretus, HE I 20[19]), then readmitted to the church. Finally, after he was made the bishop of Constantinople, he baptized Constantine (Chronicon Paschale 337, ed. L. Dindorf, Corpus Scriptorum Historiae Byzantinae 16-17, Bonn 1832, transl. M. and M. Whitby: Chronicon Paschale 284-628AD, Translated Texts for Historians 7, Liverpool 1990).

${ }^{77} \mathrm{Cf}$. Constantinus I imperator, Oratio ad sanctorum coetum 11.

${ }^{78}$ What is clear is that in Oratio ad sanctorum coetum 11 and 16, Constantine elaborates on the incarnation of Christ, on something which is intrinsic to the Christian concept of God the Trinity, but which cannot be found in Platonic understanding of God.

${ }^{79}$ Jeremy M. Schott (Christianity, Empire, and the Making of Religion in Late Antiquity, Divinations: Rereading Late Ancient Religion, Philadelphia 2008, 114-122) has advanced an argument that, in his Oratio ad sanctorum coetum, Constantine argued apologetically for the ancestral "UrMonotheism" vis-à-vis the later perversions of it in various native traditions.

${ }^{80}$ The word "henotheism" was first used by Max Müller in his Lectures on the Origin and Growth of Religion, London $1898^{3}$, and it denotes either personal veneration of one god, or belief in 
monotheism and non-Christian henotheism. Perhaps, for Constantine, henotheists were sort of "anonymous Christian monotheists" (to toy with Rahner's phrase), especially because his own religious journey had taken him from highest "pagan" gods to the one Christian God ${ }^{81}$. Yet again, what exactly did Constantine mean by the henotheism of the Most High God?

Unfortunately, he does not explain with sufficient clarity whether the use of designations "Most High" and "Supreme" excludes the existence of inferior gods, or whether these designations simply function as adjectives for the highest God among other gods. Both alternatives can be found in Scripture ${ }^{82}$. Therefore and as stated above, depending on the context of a particular religious thought-system, broad designations, such as "the Highest God", could have various meanings ${ }^{83}$. Yet, by juxtaposing the Platonic Supreme God or, "the Supreme Father" (o $\mu \dot{\varepsilon} \gamma(\sigma \tau) \varsigma \pi \alpha \tau \eta ́ \rho){ }^{84}$, to the multiple "pagan" gods, Constantine suggests that intelligent persons could do without the latter. Since the Supreme God creates everything as well as directs the course of its creation "there is no conceptual space left for any other god or other gods besides him" $" 85$. Consequently, it looks like Constantine came to prefer a view of henotheism which excluded the existence of other gods ${ }^{86}$. In other words,

one, highest God among other inferior gods, which was held by philosophers and found in various "pagan" cults, such as that of Theos Hypsistos.

${ }^{81}$ Cf. Bardill, Constantine, p. 282a.

${ }^{82}$ E.g., Deut 32, 39, "I am God and there is no God besides me", and Ex 18, 11, "Now I know that the Lord is greater than all gods". Polymnia Athanassiadi (Gods are God: Polythesitic Cult and Monotheistic Theology in the World of Late Antiquity, in: Gott oder Götter? God or Gods?, ed. T. Schabert - M. Riedl, Eranos 15, Würzburg 2009, 15-31) has cautioned that, for late antiquity and apart from Jewish-Christian tradition, monotheism/polytheism is altogether a false antithesis.

${ }^{83}$ For remarks about the ambiguous $\varepsilon \hat{i} \varsigma \theta \varepsilon o ́ s$, see Eusebius, Praeparatio evangelica 4, 5, ed. K. Mras, GCS 43/1 (Eusebius Werke 8/1), Berlin 1982, transl. E.H. Gifford: Preparation for the Gospel: Eusebius, Grand Rapids 1981. Monotheistic statements of ancient non-Christian philosophers are assessed in Michael Frede, Monotheism and Pagan Philosophy in Later Antiquity, in: Pagan Monotheism in Late Antiquity, 41-67 and The Case for Pagan Monotheism in Greek and Greco-Roman Antiquity, in: One God, 53-81. Frede is interested in emphasizing the similarity between the Christian and non-Christian concepts of the "highest God", who is "unique" and "provident", to whom other gods are "radically subordinated", and about whom "there is nothing impersonal". Therefore, he employs the term "monotheism" for both Christian and non-Christian religions and thereby arguably minimizes the differences between the respective theologies of God/god (see M. Edwards, Review of Pagan Monotheism in Late Antiquity, JTS 51 (2000) 339-342).

${ }^{84}$ Constantinus I Imperator, Oratio ad sanctorum coetum 11, GCS 7, 169.

${ }^{85}$ Frede, The Case for Pagan Monotheism, p. 58; cf. Constantinus, Oratio ad sanctorum coetum 3.

${ }^{86}$ Arguably, Constantine rejected the idea of the existence of many gods not only for theological reasons. If the microcosm of his empire reflected the macrocosm of the divine realm, then one God meant one emperor (Oratio ad sanctorum coetum 6; cf. Lactantius, Divinae institutiones I 3, 6-7, ed. S. Brant, CSEL 19, Vienna 1890, transl. A. Bowen - P. Garnsey: Lactantius, Divine Institutes, Translated Texts for Historians 40, Liverpool 2003; Eusebius, De laudibus Constantini 3, 5). Van Dam (The Roman Revolution of Constantine, p. 226) has contended that the political philosophy of Constantine developed hand-in-hand with Trinitarian theology: "Thinking about God 
it seems that the emperor gradually moved away from inclusive monotheism to exclusive monotheism with a Christian twist, and eventually also arrived at a distinction between the true God and the false gods, to the so-called, rightly or wrongly, "Mosaic distinction" 87.

At the same time, what complicates the picture further is Constantine's acknowledgment of certain plurality within this one, true, exclusive, and transcendent God. If the plurality within the Godhead indeed constitutes ontological hierarchy, then Constantine's alleged subordiantionism may look like a certain kind of ranked henotheism ${ }^{88}$. However, below it will be argued that Constantine did not promote henotheism in the "Arian"/subordinationist sense of the word. His concept of God was monotheistic, very much in the sense that the Nicene Trinitarian concept of God was and is monotheistic.

Before some further analysis, it has to be emphasized yet again that Constantine's speech was a public oration, not a private confession. Furthermore, whereas it was delivered and geared to a specific Christian audience, it was still and foremost an imperial utterance - a public display and discussion of what could be displayed and discussed publicly by the first man of the empire $^{89}$. Of course, this does not need to imply that Constantine was insincere, but it does mean that his Oratio ad sanctorum coetum does not provide a clear window into the orator's soul. Perhaps the very fact that modern interpretations of Oratio ad sanctorum coetum understand Constantine paradoxically either as (proto-)"Arian" or (proto-)Nicene shows, in its own way, that the emperor actually managed to send mixed signals. Likewise, in his own historical context, Constantine managed to be appealing to both sides - to those who

(or gods) and thinking about emperors were two aspects of the same discourse". For an argument for the thesis "one God, one emperor", see also Garth Fowden, Empire to Commonwealth: Consequences of Monotheism in Late Antiquity, Princeton 1993, especially 80-99. However, even if the public discourse about God and emperor was similar, the respective res were arguably not. The New Testament mentions Father, Son, and Holy Spirit long before the existence of imperial Tetrarchy. Furthermore, the way the emperors were ranked may have matched with henotheism or subordinationism, but definitely not with pro-Nicene Trinitarian theology, for the co-regents' power and acts were not one.

${ }^{87}$ J. Assmann, The Price of Monotheism, transl. R. Savage, Stanford 2010, 2. In time, Constantine turned against Christian sectarians and heretics as well, for "it was no longer possible to tolerate the pernicious effect of [their] destructiveness" (Eusebius, Vita Constantini III 65, 1; cf. ibidem III 63-66).

${ }^{88}$ Augustine said to a Homoean bishop Maximinus, "Shout as much as you want that the Father is greater and the Son lesser. I answer you that the greater and lesser are two" (Contra Maximinum Arianum II 23, 1, PL 42, transl. R. Teske, WSA vol. I/18, New York 1995). The accusation that

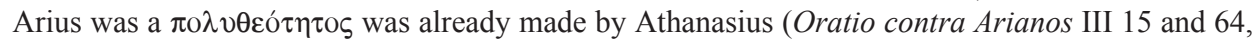
ed. M. Tetz et al., Athanasius Werke I/1, 3, Berlin 2000, transl. W. Bright: The Orations of St. Athanasius against the Arians According to the Benedictine Text, Eugene 2005).

${ }^{89}$ Arguably even his private conversations and confessions were always those of a public figure - an emperor. "Official pronouncements by any autocrat deserve to be treated with a certain skepticism” (T.D. Barnes, Constantine and Eusebius, Cambridge 1981, 242). 
were leaning towards modalism (e.g., the logos imagery ${ }^{90}$ ) and to those who preferred subordinationism (e.g., the expression "two gods") ${ }^{91}$. It was a clever way, worthy of a smart statesman, to prepare for the establishment of a hoped for consensus at the grand Council of Nicaea.

2. Constantine's God and the Nicene God. Late in 324/early 325, the Synod of Antioch produced the earliest extant synodal "creed" and by doing so, established the theological perspective which was about to dominate the Council of Nicaea. That is, it published a confession of faith, which affirmed the birth of the eternal Son from the Father and provisionally condemned those who disagreed, including Eusebius of Caesarea ${ }^{92}$.

Shortly after the Council of Antioch, some 250 bishops ${ }^{93}$ gathered at Nicaea to settle, among other more administrative tasks, the increasingly international scandal of the quarreling Alexandrian theologians. In his opening speech at the council, Constantine stated that the goal of this international conference was to settle on "one unanimous opinion shared by all"94. The gathered bishops heard this loud and clear. Nevertheless, the actual outcome of the council may have been rather disappointing to the emperor, for the theological controversy kept dragging on and on ${ }^{95}$. In fact, when Constantine died, the "Arian" con-

${ }^{90}$ The logos imagery is actually ambiguous, for it can also bolster subordinationism. See M. Edwards, Image, Word and God in the Early Christian Centuries, Ashgate Studies in Philosophy \& Theology in Late Antiquity, Farnham 2013, 138-144.

${ }^{91}$ For example, Constantine's explanation that the Son pre-existed the creation (Oratio ad sanctorum coetum 11) was acceptable both to Alexander and Arius, although in a different sense - in

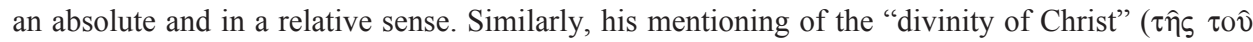

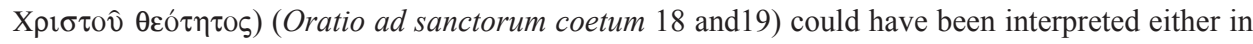
an absolute or relative sense.

${ }^{92}$ Naturally, Eusebius' Vita Constantini says nothing about this. A Greek version of the Syriac text of the "creed" of Antioch is provided by Edward Schwartz (1905), in Opitz, Urkunden zur Geschichte, nr 18.

${ }^{93}$ According to Eusthatius of Antioch in Theodoretus, HE I 8.

${ }^{94}$ A summary of the speech is given by Eusebius in his Vita Constantini III 12, 1-5. Another opening speech of Constantine, if genuine, is found in a late-fifth-century Pseudo-Gelasius, HE II 7 , 1-41, ed. G.C. Hansen, GCS NF 9, Berlin 2002.

${ }^{95}$ Cf. Rufinus, HE X 13-14, ed. E. Schwartz - T. Mommsen, GCS 9/2 (Eusebius Werke 2/2), Berlin 1908, transl. P.R. Amidon: The Church History of Rufinus of Aquilaeia, New York 1997; Socrates, HE I 23-27, 33-38. Already in 327, at Nicomedia, Constantine gave a favorable hearing to Arius and recalled his supporters from exile. In 328, the emperor reconsidered his decision, condemned Arius and his think-alikes for the second time, and ordered Arius writings to be burnt (Socrates, HE I 9). But things changed yet again in 335-336, when he asked the councils of Jerusalem and Constantinople to readmit Arius to the communion. "But Arius [...] somehow slipped back in with Constantine", summarizes Faustinus (Libellus precum 6, ed. A. Canellis, SCh 504, Paris 2006). All this does not necessarily mean that Constantine was wavering in his theological understanding. Rather, it means that "his purpose was consistent: he remained committed to the unity of faith and worship of the greatest god" and did what he deemed necessary for the religious unity of his empire (P. Stephenson, Constantine: Roman Emperor, Christian Victor, New York 2009, 272). 
troversy was only gaining momentum. The very ambiguity of Constantine's pronouncements and acts may have contributed, in their own way, to the everescalating controversy ${ }^{96}$.

The Council of Nicaea issued a creed which confessed the consubstantiality ${ }^{97}$ of the Father and the Son, and stated, "We believe in one God the Father all powerful ${ }^{98}[\ldots]$ and in one Lord Jesus Christ, the Son of God $[\ldots]$ and in the Spirit", and condemned those who taught otherwise ${ }^{99}$. Although it took decades and many tense debates to figure out what the Nicene orthodoxy really amounted to, the question posed in this article is, "How does the Nicene concept of God square with that of Constantine, who «sat on a small chair of gold» as he participated in the conciliar discussions about God?"100

The way Constantine wanted everyone to perceive the landmark Council of Nicaea can be seen from his letters sent immediately after the gathering. The council and its creed were optimistically referred to as a "unanimous agreement, so that nothing remained to cause further difference of opinion or dispute about faith"101. At Nicaea, something was agreed upon indeed which allowed hope for the much desired unity - a common date of Easter for all Christians ${ }^{102}$. Interestingly, in his post-conciliar letter to the churches in general, Constantine spent almost all textual space on this religious festival rather than on the Christian concept of God - evidently because, at Nicaea, there was little evidence about theological consensus: some documents were torn to pieces, the dissenters were compelled to assent and sign the documents ${ }^{103}$, and those who

\footnotetext{
${ }^{96}$ Cf. Norderval, The Emperor Constantine and Arius, p. 115.

${ }^{97}$ The word homoousios is mentioned nowhere in Constantine's extant letters and speeches, but see Ambrose, De fide [ad Gratianum Augustum] III 15, 125, ed. O. Faller, CSEL 78, Vienna 1962, transl. NPNF II/10. A subordinationist Philostorgius (HE II 1) even contended that it was not the good Emperor Constantine, but the dreaded Alexander and Ossius who collaborated in having the council promulgate the completely misleading term homoousios. Accordingly, Constantine "sent letters everywhere disparaging the term homoousios and endorsing heteroousios"!

${ }^{98}$ In his letter to Shapur, Constantine employed a similar phrase "in confessing this one God the

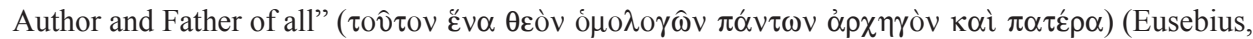
Vita Constantini IV 11, 1, GCS (Eusebius Werke 1/1), 122).

${ }^{99}$ Cf. Concilium Nicaenum (325), ed. G. Alberigo, in: Conciliorum Oecumenicorum Generaliumque Decreta, vol. 1, Turnhout 2007, 3-15.

${ }^{100}$ Eusebius, Vita Constantini III 10, 5, GCS (Eusebius Werke 1/1), 86; but see also IV 33, 2. However, in HE I 1, Socrates complains that Eusebius was "more intent on [...] the praises of the emperor than on an accurate statement of facts".

${ }^{101}$ Eusebius, Vita Constantini III 17, 2, GCS (Eusebius Werke 1/1), 90.

${ }_{102}$ M. DelCogliano, The Promotion of the Constantinian Agenda in Eusebius of Caesarea's "On The Feast of Pascha", in: Reconsidering Eusebius: Collected Papers on Literal, Historical, and Theological Issues, ed. S. Inowlocki - C. Zamagni, Leiden 2011, 39-68.

${ }^{103}$ Rufinus (HE X 5) says that while six bishops were expelled together with Arius, eleven signed the documents "with hand only, not heart". For the attendants and their subscribing various conciliar documents, see Sarah Parvis, Marcellus of Ancyra and the Lost Years of the Arian Controversy 325-345, Oxford Early Christian Studies, Oxford 2006, 38-95.
} 
did not, were anathemized. Once again, it is quite remarkable that while about one third of the council's letter to the Egyptians concerned the doctrine of God and Arius' alleged misunderstanding of it ${ }^{104}$, in his imperial letter, Constantine had nothing to say about the doctrine of the Triune God. True, he discussed the Lord's Day of resurrection, but this discussion was introduced by the usual

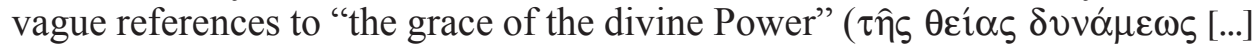

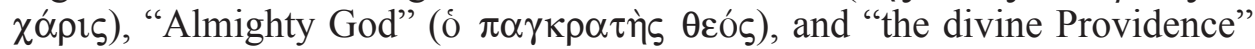
(i $\theta \varepsilon i ́ \alpha$ Прóvor $\alpha)^{105}$. Something similar is true about Constantine's letter to the Alexandrians. He mentions Arius once, but says nothing specific about his theology or the conciliar theological debates ${ }^{106}$. And although Constantine also refers to the Holy Spirit and Savior, he operates again with all-inclusive

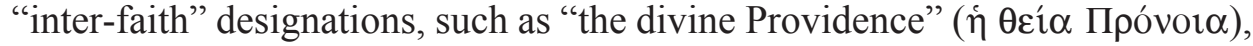

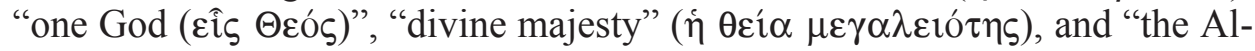
mighty" (o $\pi \alpha v \tau$ oкрó $\tau \omega \rho)$. The names "Christ", "Jesus", and the expression "the Son of God" do not occur in these letters. Yet, the emperor never forgot to emphasize that "more than three hundred bishops $[\ldots]$ were unanimous in

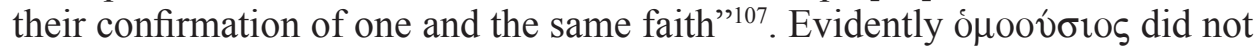
matter as much as ó $\mu$ ovoí $\alpha$ did!

All this suggests that it is still primarily Constantine's Oratio ad sanctorum coetum which provides some opportunities for comparing the emperor's doctrine of God to that of Nicaea.

In this speech, the transcendent God that Constantine envisions "is forever

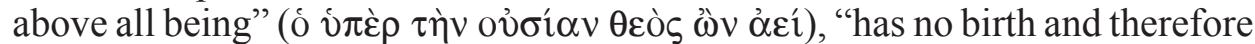

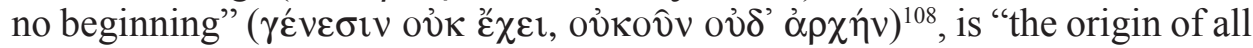

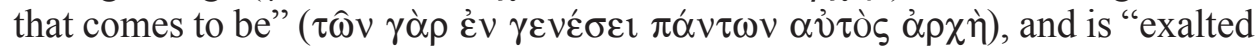

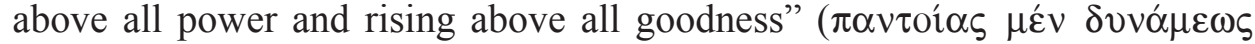

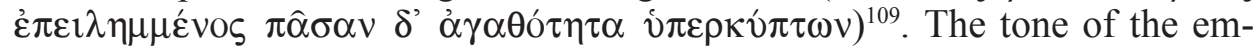
peror's discourse is philosophical, abstract, and sufficiently accommodating.

Nevertheless, Constantine's transcendent God was undoubtedly a Christian God. In order to affirm the diversified unity of the one transcendent God, Constantine turned to the idea of the Son as the $\log _{0 s^{110}}$. He contends that

${ }^{104}$ Cf. Socrates, HE I 9.

${ }^{105}$ Eusebius, Vita Constantini III 17, 1 - 19, 2, GCS (Eusebius Werke 1/1), 89-92.

${ }^{106} \mathrm{Cf}$. Socrates, HE I 9.

${ }^{107}$ Ibidem I 9, GCS NF 1, 32.

${ }^{108}$ While an inscription from Oenoanda calls the Theos Hypsistos "self-born" (M. Beard J. North - S. Price, Religions of Rome, vol. 2: A Sourcebook, Cambridge 1998, 2.10a), Christians call the Father "Unbegotten" and the Son "Only-begotten".

${ }^{109}$ Constantinus I Imperator, Oratio ad sanctorum coetum 3 and 11, GCS 7, 156 and 167. In Oratio ad sanctorum coetum 3 and 23, Constantine equates "the good" ( $\dot{\alpha} \gamma \alpha \theta$ óv) with the transcendent God as well.

${ }^{110}$ The emperor ends his Introduction to Oratio ad sanctorum coetum (1) by saying that he

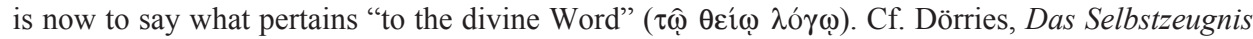
Kaiser Konstantins, p. 148-149. 
a twofold "one God" is comprised of the Father and "the Word" (o $\lambda o ́ \gamma o \varsigma$ )

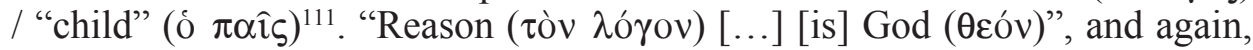

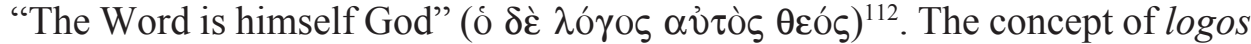
helped Constantine to rescue the idea of the oneness of God and also to "accommodate" the Son of God into the one God. There is "one God [...] who sets all things in order by his Word $(\lambda o ́ \gamma \omega)$ "'113.

It is not entirely clear, however, what Constantine says next about the Son of God in his Oratio ad sanctorum coetum 3. His words in Oratio ad sanctorum coetum 11 prove that the emperor was certainly aware of "the double

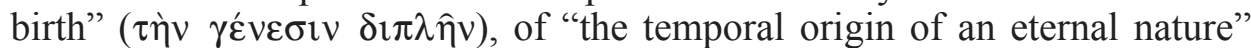

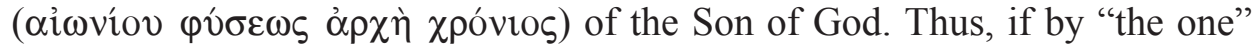
(the definite article o), in Oratio ad sanctorum coetum 3, Constantine means the incarnated Son, then to assert, economically, that "he received his begin-

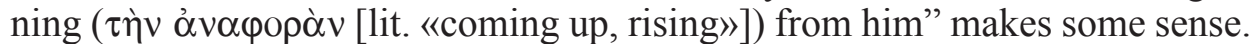
But if "the one" means the Son before his incarnation, then "a few passing comments on God and his Word [come] horribly close to [Arius'] heresy"114. Likewise, the fourth sentence states that "the one begotten has come to be ( $\sigma v v \varepsilon \dot{\sigma} \sigma \eta)$ " and the question is again whether the future pro-Nicene Trinitarian theologians could have accepted this statement, because the eternal Son neither "has a beginning" nor "comes to be"

However, Constantine's understanding of God is not at all so "Arian" as it initially may seem ${ }^{116}$. First, the birth of the $\operatorname{Son}^{117}$ is not supposed to be understood as a division of the divine nature ${ }^{118}$. Instead, it should be understood

${ }^{111}$ Constantinus I Imperator, Oratio ad sanctorum coetum 9, GCS 7, 163; cf. Jn 1, 1. In Oratio ad sanctorum coetum 11 and 18, Constantine says epexegetically that blasphemers blame "Christ,

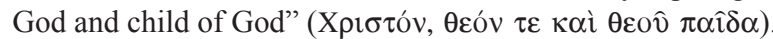

${ }_{112}$ Ibidem 8-9, GCS 7, 162-163. Since God can never be alogos, the logos has to be co-eternal with God.

${ }^{113}$ Ibidem 9, GCS 7, 163; cf. Alcuinus Flaccus, Epitome I 10, 3, ed. P. Louis, Nouvelle Collection de Textes et Documents, Les Belles Lettres, Paris 1945. In Enneads V 1, 6 (transl. A.H.

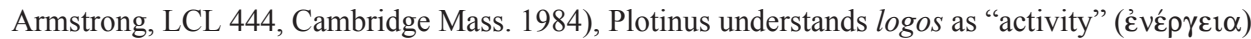
which actualizes that which emanates from the One. Constantine usage, in turn, allows one to perceive logos either hypostatically or anhypostatically.

${ }^{114}$ Fox, Pagans and Christians, p. 644, 646, and 654.

${ }^{115}$ Constantine (Oratio ad sanctorum coetum 4 ) himself explains that "a temporal beginning is

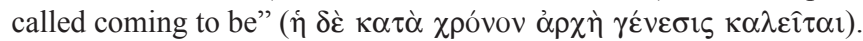

${ }^{116}$ See M. Edwards, The Arian Heresy and the Oration to the Saints, VigCh 49 (1995) 379-387 and Constantine's agitated letter against the stubborn Arius (Opitz, Urkunden zur Geschichte, nr 34).

${ }^{117}$ The analogy of or the argument from birth is significant. While Scripture employs the designation "the son of the Most High" (Sir 4, 10; Lk 1, 32; but "sons" in Ps 82, 6), a "pagan" grammarian Maximus of Madaura asked Augustine, "Who is so demented, so mentally incapacitated as to deny that it is most certain that there is one highest God, without beginning, without natural offspring (sine prole naturae), the great and magnificent father, as it were?" (Augustinus, Epistula 16, 1).

${ }^{118}$ Cf. Constantinus I Imperator, Oratio ad sanctorum coetum 3; see Opitz, Urkunden zur Geschichte, $\mathrm{nr} 27,2-4$. 


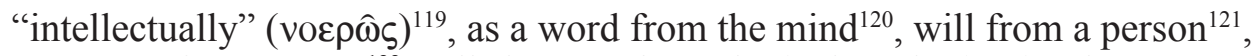
or power from nature ${ }^{122}$. All these anthropological analogies imply co-temporality of the mentioned elements. By implication, they can also imply the co-eternality of the Father and the Son.

Second, since Constantine immediately rejects the analogy of birth as it is known from the created word, the intellectual understanding of the birth of the Son arguably excludes any kind of temporal gap between the Father and the Son. In Oratio ad sanctorum coetum 11, where Constantine comes back to the notion of the divine birth, he adds that the begetting of the "child" has to match with the facts that the eternal Son does not have a Mother - although the temporal, incarnated Son has a mother. Furthermore, in Oratio ad sanctorum coetum 4, Constantine's discussion of things which come to be and cease to be is not concerned with the birth of the divine Son at all, but rather with "pagan" gods ${ }^{123}$. He is very clear about a vast difference between the created realities and the eternal uncreated realities, including the begotten Son, who has "nei-

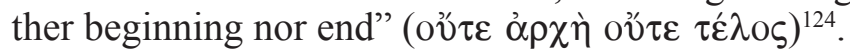

Things get really interesting in Oratio ad sanctorum coetum 9, where Plato is said to have postulated "the god above being, then made a second subordi-

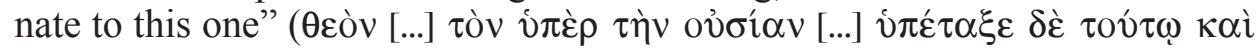
$\delta \varepsilon v ́ \tau \varepsilon \rho o v)$. Had Constantine stopped here, he would have come across as a definite subordinationist ${ }^{125}$. But he continued, "Both shared one perfection and the

${ }^{119}$ Ibidem 3 and 6, GCS 7, 156 and 160; cf. Alcuinus Flaccus, Epitome I 10, 4.

${ }^{120}$ In Oratio ad sanctorum coetum 6, Constantine employs the Stoic anthropological distinction between the internal and the expressed word (Sextus Empiricus, Adversus mathematicos VIII 275276, transl. R.G. Bury, LCL 291, Cambridge 1935), which was used theologically for explaining the "second God", at least since Theophilus of Antioch (Ad Autolycum 2, 10; 2, 22, ed. and transl. R.M. Grant, Oxford Early Christian Monographs, Oxford 1970). Such analogy was condemned in 351, at the Homoean council of Sirmium, but was nevertheless continually used by various theologians, such as Augustine.

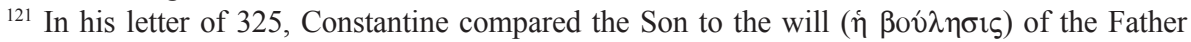
(Opitz, Urkunden zur Geschichte, nr 27, 2), which likewise proceeds eternally from the eternal Father.

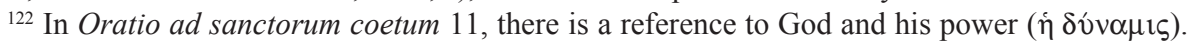
Cf. Dörries, Das Selbstzeugnis Kaiser Konstantins, p. 380-384.

${ }^{123}$ Cf. Constantinus I Imperator, Oratio ad sanctorum coetum 14: "To compare things that come to be with those that are eternal [presumably God and his Logos] is in truth the most perfect madness. For the former have neither beginning nor end; the latter, inasmuch as they have grown and come into being and receive temporal origin of their existence and life, are also subject to death as a necessary consequence".

${ }^{124}$ Ibidem 14, GCS 7, 173.

${ }^{125}$ Rufinus (HE X12) mentions Empress Constantia's meddling in theological affairs, as a result of which Constantine befriended a mysterious "Arian" presbyter and reassessed the results of Nicaea. Jerome, in turn, contended that, having been baptized by Eusebius of Nicomedia, Constantine "went off down into the Arian doctrine" (Chronicon 337, ed. R. Helm, GCS 47 (Eusebius Werke 7), Berlin 1984, transl. M.D. Donalson: A Translation of Jerome's Chronicon with Historical Commentary, Lewiston 1996). 
essence of the second god received its concrete existence from the first" ( $\mu 1 \hat{\alpha} \varsigma$

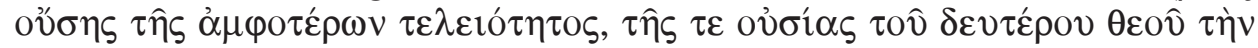

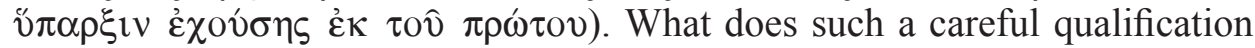
suggest? It suggests that, just like the phrase "second god" 126 , subordination can be interpreted in both heterodox and orthodox sense. It can mean ontological and temporal subordinationism, which is "Arianism"; and it can also mean causal or logical subordinationism, which matches with (later) Trinitarian orthodoxy and draws on the traditional doctrine of the monarchy of the Father ${ }^{127}$. So, once again, Constantine contended that the "second god" received

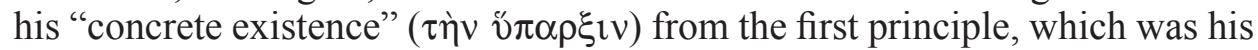
"cause" ( $\dot{\eta} \alpha i \tau i \alpha)$; and in Oratio ad sanctorum coetum 11, "Just as the Father

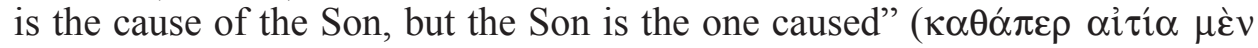

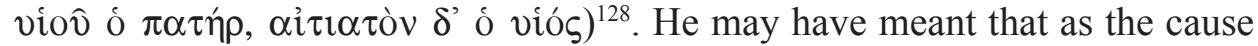
(i.e., the Father) was eternal ${ }^{129}$, so was the effect (i.e., the Son) ${ }^{130}$. Thus, to say that the Son was caused is not necessarily "Arian" subordinationism.

Furthermore, although God (Father) was the cause of both his Son and "of all [created] things" ( $\tau \hat{\eta} \varsigma \tau \hat{\omega} \nu \pi \alpha ́ v \tau \omega \nu)^{131}$, he was the cause of both in a different sense. The "second God" was his own (' $1 \delta 10 \varsigma)$ and as such, begotten form the first, not created by him ${ }^{132}$. From the perspective of the soon-to-be synodal orthodoxy, there was really nothing wrong with emperor's claims ${ }^{133}$, especially because, in the same chapter, Constantine explicitly affirmed both the oneness of God and the divinity of the Son ${ }^{134}$. He argues that the "first" and "second God" had to be distinguished ,numerically" ( $\tau \hat{\omega} \hat{\alpha} \alpha \rho \theta \mu \hat{\omega})$, but not ontologically or temporarily ${ }^{135}$.

To conclude, reconstruction of Constantine's doctrine of God depends heavily on which of his theological statements are given priority, for it is not always clear how and whether everything he says actually coheres. Because

${ }^{126}$ Cf. Origenes, Contra Celsum V 39; VI 61; Eusebius, Praeparatio evangelica 11, 14 and 18 (citing Numenius, Frg. 12 [Des Places]). However, identifying the possible sources of some ideas and vocabulary is not yet establishing the meaning of these ideas and vocabulary in other thought-systems.

${ }^{127}$ In Oratio ad sanctorum coetum 23, Constantine actually uses the word $\mu$ ov $\alpha \rho \chi i \alpha$.

${ }^{128}$ Cf. Plotinus, Enneades V 1, 8.

${ }^{129}$ In Oratio ad sanctorum coetum 11, Constantine indeed speaks about the Son being from God

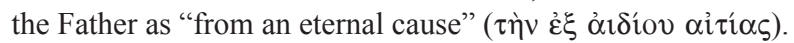

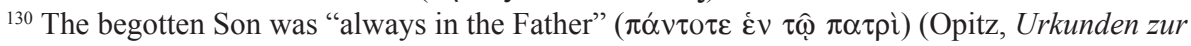
Geschichte, nr 27, 2).

${ }^{131}$ Consider the notorious punctuation problem in Jn 1, 3-4.

${ }^{132}$ Cf. Constantinus I Imperator, Oratio ad sanctorum coetum 9; Opitz, Urkunden zur Geschichte, $\mathrm{nr} 27,2$.

${ }^{133}$ The Nicene Creed confesses: "God from God [...] true God from true God".

${ }^{134}$ Constantine hymns interchangeably "the true God", "Christ", and "the Father" (Oratio ad sanctorum coetum 5, 11 and 17). See Jn 17, 3 and the ambiguous 1Jn 5,20.

${ }^{135}$ For the "uniplurality" of numbers, see Plato, Theaetus 185a-b, transl. H.N. Fowler, LCL 36, Cambridge 1921, and Plotinus, Enneades V 1, 5. 
of the emperor's constant concern for establishing politically safe theological consensus, his resilient utterances were perhaps deliberately designed to be heard according to one's religious preference. Yet, the gradual shift from the general designations of God to the more specific Christian designations, as well as his intention to conform to the Nicene concept of God seems undeniable. In the beginning of the fourth century, the imperial agenda and ecclesiastical conviction shared common interests, but while one strived for the widest possible acceptability of the doctrine of God, the other strived for the rightness of it. No doubt, Constantine's Summus Deus was meant to match with the restricted Nicene Unus Deus, but the Nicene Unus Deus was not necessarily the all-inclusive Summus Deus.

\section{SUMMUS DEUS KONSTANTYNA I NICEJSKI UNUS DEUS: CESARSKA I KOŚCIELNA KONCEPCJA BOGA}

\section{(Streszczenie)}

Cesarz Konstantyn Wielki w zachowanych listach i mowach wielokrotnie odnosił się do Boga. Odniesienia te jednak rzadko przybierały postać rozważań teologicznych na temat Jego istoty; zwykle ograniczały do wykorzystywania pewnych ambiwalentnych Jego tytułów. W niniejszym artykule przeanalizowano cesarską koncepcję Boga przy pomocy tak zwanej „,małej teologii”. Wygląda na to, że konstantyńskie rozumienie Boga rozwinęło się z zamkniętego pogańskiego henoteizmu w zaawansowany chrześcijański monoteizm, mimo że zachowało rys wiary w istnienie wielu postaci Boga. Niejasność kwestii teologicznych służyła ustanowieniu możliwie najszerszego kompromisu teologicznego w Cesarstwie Rzymskim. W tym samym czasie owa zamierzona niejasność wpłynęła na różne sposoby interpretowania konstantyńskich wypowiedzi teologicznych i - być może - w pośredni sposób oddziaływała na trynitne spory w łonie Kościoła. Porównanie konstantyńskiej i nicejskiej koncepcji Boga pokazuje zarówno ważny kompromis, jak i istnienie różnorakich, leżących u jego podstaw czynników.

Key words: concept of God, Constantine, letters, speeches, christianity, Nicean creed.

Słowa kluczowe: koncepcja Boga, Konstantyn, listy, mowy, chrześcijaństwo, nicejski symbol wiary. 